\title{
Hiperrealitas Sosok Suami Tenaga Kerja Wanita (TKW) Dalam Sinetron Dunia Terbalik Di RCTI
}

\author{
Nuria Astagini $^{1}$, Fitriyah Nurhidayah ${ }^{2}$ \\ ${ }^{1}$ Program Studi Ilmu Komunikasi, Universitas Pembangunan Jaya, nuria.astagini@upj.ac.id \\ ${ }^{2}$ Program Studi Akuntansi, Universitas Pembangunan Jaya, fitriyah.nurhidayah@upj.ac.id
}

\begin{abstract}
For some Indonesian women, working as a domestic migrant workers is one of the way to help their families rise out of poverty. Unfortunately their families, especially the husband, do not fully suppoted their struggle as domestic migrant workers. Several studies have shown that the majority of Indonesian migrant worker's husband often betrayed their wives, abandoned their families, and performed various disgraceful behaviors. "Dunia Terbalik", a television show which is aired in RCTI gave a different portrayal of Indonesian migrant worker's husband. They are portrayed as an ideal husband, which sincerely perform the role of "househusband". Referring to Jean Baudrillard's hiperreality, than these portrayals of Indonesian migrant worker's husband can be defined as hiperreality; where simulation from reality created new reality, which covers a true reality. The ideal husband which is portrayed in this television show, who put their wives in the dominant position is hyperreality, which is different with the real situation. Hyperreality shown in this television show could be a starting point for gender equality and contributing in eliminate negative stigma that attached to Indonesian migrant workers and their families.
\end{abstract}

Keywords :hyperreality, gender, roles, women migrant woker, television show, stigma, negative

\begin{abstract}
Abstrak : Bagi sebagian perempuan Indonesia, bekerja menjadi Tenaga Kerja Indonesia (TKI) luar negeri adalah salah satu cara untuk membantu keluarga keluar dari kemiskinan. Sayangnya perjuangan kaum perempuan yang bekerja sebagai TKI ini kadang tidak didukung oleh suami dan keluarga mereka. Banyak suami TKI yang menyalahgunakan kepercayaan dari istri -istri mereka, menelantarkan keluarga; bahkan menggunakan uang kiriman dari sang istri untuk berbagai perilaku menyimpang. Melalui sinteron "Dunia Terbalik" yang ditayangkan di RCTI ini kita diajak untuk melihat sosok suami TKI yang sangat bertolak belakang dari suami TKI pada umumnya. Sinetron ini menggambarkan suami yang dengan ikhlas menerima tugas sebagai "bapak rumah tangga". Hal inilah yang disebut Jean Baudrillard sebagai hiperrealitas, dimana simulasi dari realitas menciptakan realitas baru atau hiperralitas yang menyelubungi realitas yang sebenarnya. Para suami diperlihatkan ikhlas menggantikan peran istri dan meletakkan kekuasaan mutlak di tangan istri. Hiperrealitas yang diperlihatkan pada sinetron ini dapat menjadi titik awal yang memunculkan konsep kesetaraan gender, serta berkontribusi untuk menghapuskan stigma negatif yang melekat pada kalangan TKI serta keluarga mereka.
\end{abstract}

Kata Kunci : hiperrealitas, gender, peran, TKW, sinetron, stigma, negatif

\section{PENDAHULUAN}

Bekerja sebagai TKI (Tenaga Kerja Indonesia) di luar negeri menjadi solusi bagi permasalahan ekonomi yang dihadapi oleh sebagian besar masyarakat di Indonesia. Sebagian besar individu yang memutuskan untuk menjadi tenaga kerja Indonesia ke luar negeri berasal dari status 
sosial menengah bawah. Mereka memilih bekerja jauh dari keluarga karena mengharapkan penghasilan yang layak dan dapat membantu keluarga keluar dari kemiskinan (Syafitri, 2012). Indonesia sendiri termasuk salah satu negara yang paling banyak mengirimkan tenaga kerjanya ke luar negeri. Pada tahun 2015 Badan Nasional Penempatan dan Perlindungan Tenaga Kerja Indonesia (BNP2TKI) mencatat bahwa jumlah TKI di luar negeri berkisar pada 6,5 juta jiwa dan diperkirakan akan terus bertambah.

Serikat Buruh Migran Indonesia (SBMI) mencatat bahwa sebesar $62 \%$ TKI berjenis kelamin perempuan, dan sebagian besar bekerja pada sektor domestik atau menjadi pekerja rumah tangga (Indonesia, 2017). Para perempuan ini yang berperan sebagai pencari nafkah utama bagi keluarga mereka. Sayangnya seringkali posisi mereka seakan terlupakan oleh pemerintah Indonesia. Dalam banyak kasus hukum yang menjerat tenaga kerja Indonesia di luar negeri, pemerintah Indonesia tidak memberikan perlindungan hukum yang jelas, sehingga banyak tenaga kerja Indonesia yang mengalami kekerasan, pelecehan, pemerasan, hingga menjadi korban perdagangan (trafficking) (Maulani, 2010). Para perempuan yang bekerja sebagai TKI biasa disebut dengan Tenaga Kerja Wanita (TKW).

Perjuangan kaum perempuan yang bekerja ke luar negeri juga kadang tidak tidak diimbangi dukungan suami dan keluarga mereka. Masih banyak suami yang enggan dan gengsi untuk sekedar mengucapkan terima kasih kepada istri mereka; bahkan ada yang menggunakan uang kiriman dari istri mereka untuk berbagai perilaku menyimpang seperti mabuk, menjalin hubungan dengan wanita lain atau berjudi (Muzakki, 2017). Kehidupan para TKW dan keluarganya ini yang kemudian diangkat ke layar televisi melalui sinetron terbaru produksi MNC Production yang berjudul "Dunia Terbalik".

Sinetron ini menggambarkan potret kehidupan sebagian masyarakat Indonesia, dimana para perempuan berperan menjadi tulang punggung keluarga dengan bekerja menjadi TKW (Tenaga Kerja Wanita) ke luar negeri. Suami yang biasanya berperan untuk menafkahi istri dan keluarga, dalam sinetron ini berbalik dan digantikan oleh sang istri. Suami bertugas untuk mendidik anak serta mengurus urusan rumah tangga. Selain memperlihatkan peran suami dan istri yang berbeda dari sinetron pada umumnya, sinetron ini juga memberikan gambaran yang berbeda mengenai stereotype yang melekat pada suami suami TKW.

Di Indonesia sendiri televisi merupakan institusi sosial yang mampu meraih perhatian penonton dengan skala dan intensitas yang sangat besar. Melalui program yang ditayangkannya, televisi mampu meraih perhatian kurang lebih 100 juta penonton di seluruh Indonesia (Heryanto, 2008). Dari berbagai acara yang ditayangkan di televisi, acara yang paling banyak dikonsumsi oleh penonton televisi di Indonesia adalah program serial televisi (sinetron). Hasil riset Nielsen memperlihatkan bahwa penonton televisi di Indonesia menghabiskan 20 persen waktu konsumsi televisi untuk menonton tayangan sinetron ("Sinetron Masih Merajai Program TV Lokal”, 2015).

Berbagai gambaran yang ditampilkan dalam acara televisi menjadi pembahasan yang signifikan; karena dalam masyarakat modern, individu banyak menghabiskan waktu untuk mengkonsumsi media, terutama televisi. Ritzer (2011) dalam Saputra (2016, h. 11) menyatakan bahwa menurut Baudrillard, media mulai tidak menjadi cerminan dari realitas yang ada di tengah-tengah masyarakat. Media menampilkan suatu bentuk realitas baru dan disuguhkan lebih riil dari realitas yang sesungguhnya. Hal inilah yang disebut Jean Baudrillard sebagai hiperrealitas, dimana simulasi dari realitas menciptakan realitas baru atau hiperralitas yang menyelubungi realitas yang sebenarnya. Dalam hipperrealitas, realitas palsu dan realitas 
asli bercampur sehingga sulit dibedakan. (Chardon, 2014)

Baudrillard merasa bahwa realitas sudah mati, dan kita hidup di dunia hiperrealitas yang luas. Hiperrealitas adalah keadaan dimana tanda-tanda memiliki kehidupannya sendiri,lepas dari realitas dan mengambang bebas. Tanda merupakan refleksi dari realitas, tetapi sekarang merupakan bagian dari permainan yang tertata, yang dimainkan demi kepentingannya sendiri (O'Donnell, 2009, h. 45).

\section{Permasalahan}

Permasalahan yang akan dikaji adalah bagaimana hiperrealitas yang diperlihatkan dalam sinetron Dunia Terbalik?

\section{Tujuan Kajian}

Kajian ini bertujuan untuk melihat bagaimana konsep hiperrealitas digunakan dalam peleburan realitas terkait sosok suami dalam sinetron "Dunia Terbalik", dan bagaimana realitas tersebut ditampilkan pada sinetron "Dunia Terbalik"

\section{KAJIAN PUSTAKA \\ Jean Baudrillard}

Jean Baudrillard (1929-2007) adalah seorang Filsuf Prancis yang banyak membahas mengenai masyarakat konsumsi. Baudrillad melihat semua objek yang dikonsumsi sebagai sebuah sistem tanda yang harus dimaknakan kembali. Pada negara-negara yang sangat kapitalis, barang konsumsi juga memiliki nilai pertukaran tanda, tanda yang menjadi pembeda (distinction) yang menentukan selera dan status sosial seseorang. Baudrillard juga membayangkan sebuah alam utopia dimana semua manusia ikut serta dalam pertukaran simbolik. Baudrillard juga membahas mengenai media, dan bagaimana media mempengaruhi persepsi terhadap dunia dan realitas. Ia mengatakan bahwa dalam kondisi post-modern "media laden", kita mengalami sesuatu yang dikatakan sebagai kematian dari realitas. Sehingga kita hidup di alam hiperreal, dan memiliki hubungan yang sangat dalam dengan media seperti serial televisi, video musik, virtual reality games, atau taman hiburan, serta berbagai hal yang menstimulasi realitas. Dalam kondisi ini Baudrillard mengatakan bahwa kita telah berserah pada kekuatan seduktif dari media massa, baik televisi, iklan, film, majalah dan surat kabar (Mann, n.d)

\section{Simulasi dan Hiperrealitas}

Baudrillard mengatakan bahwa dalam budaya post modern yang didominasi oleh televisi, film, surat kabar dan internet; pemikiran mengenai benar tidaknya tiruan dari sebuah realitas telah hancur, dan sekarang kita berada dalam era simulasi realitas (Mann, n. d).

Simulasi merupakan proses representasi atas suatu obyek yang justru kemudian berubah mengganti obyek itu sendiri. Lalu representasi menjadi sedikit lebih penting daripada obyek tersebut. Perbedaan antara simulasi sakit dan purapura sakit terletak pada simtomnya. Purapura sakit sakit cukup meniru salah satu atau dua simtomnya saja, sedangkan simulasi harus memproduksi semua simtom penyakit itu,bahkan lebih daripada simtom yang biasa ada. Dengan kata lain, yang riil dibuat dari unit-unit yang diminiaturisasi, dari acuan-acuan, dari tumpukan beragam ingatan,namun tidak harus rasional, karena tidak lagi diukur dari yang ideal atau penyempurnaan dari yang negatif (Haryatmoko, 2016, h. 80).

Baudrillad (1981, h. 11) dalam Haryatmoko (2016, h. 80-81) menjelaskan bahwa zaman ini ditandai sebagai era simulasi yang dimulai dengan menghapuskan acuan-acuan. Caranya dengan membangkitkan yang artifisial dalam sistem tanda. Simulasi memang bukan lagi masalah meniru atau membuat duplikatnya, bukan pula suatu bentuk parodi, tetapi masalah menggantikan tandatanda yang riil yang kemudian justru diperlakukan seakan sebagai yang riil itu 
sendiri. Disneyland digunakan sebagai contoh oleh Baudrillard karena taman ini merupakan model sempurna semua tatanan simulasi di mana dikembangkan permainan ilusi dan fantasi. Dalam simulasi,pertanyaan tentang riil dan fiksi,nyata dan palsu menjadi tidak relevan lagi (Haryatmoko, 2016, h. 82).

Hiperrealitas menjelaskan
bagaimana permainan tanda-tanda berlangsung, bagaimana antara yang riil dan yang semu/palsu, berbeur atau melebur (sehingga keaslian dan kepalsuan sulit dibedakan), dan bagaimana dunia tiruan dapat terbentuk (Lubis, 2015, h. 81). Dalam dunia hiperrealitas, tidak mungkin untuk mencari sumber,atau realitas yang sebenarnya. Dengan kata lain, saat ini tidak ada lagi realitas kita hidup dengan hiperrealitas, yang dikarakteristikkan oleh reproduksi; yaitu produksi yang mendominasi era industri.

Saat ini Baudrillard mengatakan bahwa kita mengambil "peta realitas" seperti acara televisi, film, dan lain sebagainya sebagai sebuah hal yang lebih nyata dibandingkan kehidupan kita. Simulakra (tiruan hiperreal) ini mendahului kehidupan kita. Sahabat yang kita dapatkan melalui televisi(karakter atau tokoh pada sebuah acara televisi) dapat menjadi lebih nyata dibandingkan sahabat kita di kehidupan yang sebenarnya. Komunikasi yang dilakukan melalui email, atau hubungan dengan karakter dalam video games menjadi lebih baik dibandingkan dengan hubungan dengan keluarga. Pada akhirnya Baudrillard mengatakan bahwa saat ini kita hidup dengan di sebuah ruang budaya, dimana televisi, film, dan gambaran darikomputer menjadi lebih nyata dibandingkan kehidupan kita yang sebenarnya (Mann,n.d)

\section{Gender dan Peran}

Laki - laki dan perempuan secara fisik berbeda, namun keduanya memiliki posisi yang setara dan peran tertentu di dalam masyarakat. Terdapat perbedaan antara gender dan jenis kelamin. Jenis kelamin dipandang sebagai keadaan biologis yang membedakan antara laki-laki dan perempuan. Sementara gender digunakan untuk mendefinisikan peran seseorang di dalam masyarakat. Gender merupakan karakteristik psikologis, sosial, budaya dan perilaku yang diasosiasikan dengan jenis kelamin tertentu. Oleh karena itu gender merupakan interpretasi masyarakat dari suatu kelompok budaya tertentu terkait peranan yang harus dilakukan seorang lakilaki atau perempuan (Wienclaw, 2011, h. 78).

Hal inilah yang akhirnya memunculkan stereotype terhadap gender. Sebagai contoh stereotype yang melekat pada gender adalah perempuan yang harus tinggal di rumah dan mengurus rumah tangga; sementara pata laki-laki bekerja dan memberikan nafkah bagi keluarganya. Stereotype ini seakan terbantahkan dengan fakta bahwa banyak juga kaum perempuan yang mendapatkan kesuksesan dalam karir dan mampu menafkahi keluarga mereka. Hal ini memperlihatkan bahwa kemampuan seseorang, bukan gender atau jenis kelamin yang seharusnya menjadi parameter bagi laki-laki atau perempuan. Namun tentu saja hal ini masih sulit diterima bagi sebagian besar masyarakat, terutama yang memiliki budaya patriarki (Wienclaw, 2011, h. 78). Boswell, 2003; Lorber, 2003 dalam Wienclaw, 2011, h. 78, mengatakan bahwa untuk memahami konsep gender dan maknanya, maka individu juga harus memahami budaya dan interaksi sosial yang terdapat pada sebuah kelompok masyarakat. Karena gender dapat diinterpretasikan secara berbeda tergantung pada budaya dan lingkungan sosial kelompok masyarakat tertentu. Dalam sebuah keluarga, terdapat pandangan tradisional terkait dengan gender; dimana peran yang diberikan kepada suami dan istri berbeda. Suami harus menghasilkan uang, sementara istri harus berperan menjaga dan mengurus keluarga.

Seiring dengan perkembangan zaman, terjadi perubahan dalam pembagian peran 
dalam tanggung jawab domestik/rumah tangga. Perempuan kini sudah banyak yang memasuki dunia kerja dan mendapatkan posisi yang setara dengan laki-laki, sehingga pembagian kerja rumah tangga juga harus mendapatkan penyesuaian. Norma dan nilai yang terdapat dalam masyarakat juga diharapkan dapat berubah (Wienclaw, 2011, h. 79). Tanpa disadari, stereotype gender ini selain merugikan perempuan juga merugikan laki-laki. Faludi dalam Gauntlett (2011) menjelaskan bahwa dengan tanggung jawab yang diberikan sebagai pencari nafkah utama,laki-laki kehilangan kesempatan untuk menjalin hubungan yang baik dan dekat dengan istri, anak-anak dan anggota keluarga lainnya. Tuntutan untuk sukses di dunia kerja juga dapat membuat laki-laki merasa tidak bahagia.

Beberapa tahun terakhir terdapat pergeseran peran terkait gender di media massa. Awalnya laki-laki selalu ditampilkan sebagai sosok yang aktif, tegas, berani, pintar dan banyak akal. Perempuan hanya ditampilkan sebagai pelengkap,meski ada beberapa acara televisi yang menampilkan perempuan sebagai tokoh utama. Di berbagai majalah dan iklan yang mensasar target market perempuan, berbagai isi dan iklan cenderung mendorong stereotype perempuan sebagai ibu rumah tangga yang feminin (Gauntlett, 2011). Namun pada tahun 1990-an, laki-laki dan perempuan mulai diperlihatkan bekerja sama sebagai kolega, menempati posisi yang setara dan berbagai serial televisi (Gauntlett, 2011). Kini perempuan digambarkan sebagai tokoh yang independen, sementara penggambaran maskulinitas yang biasanya lekat dengan laki-laki sekarang menjadi kurang diperlihatkan.

\section{Konflik Peran dalam Rumah Tangga}

Konflik dapat muncul ketika individu dalam sebuah hubungan memiliki peran yang saling berkompetisi ataupun peran yang bertolak belakang. Ahli Sosiologi Robert Merton menggambarkan permasalahan terkait konflik peran menjadi dua jenis, yaitu konflik peran intrapersonal dan konflik peran interpersonal. Konflik peran intrapersonal merujuk pada konflik yang muncul antar individu. Konflik ini seringkali muncul dalam situasi perkerjaan, dan terkait dengan harapan yang diasosiasikan dengan peran yang berbeda. Sedangkan konflik peran interpersonal merupakan konflik yang muncul dari peran yang saling berkompetisi yang secara simultan dilakukan oleh seorang individu. Kedua konflik ini dapat menimbulkan tekanan, stress dan perilaku antisosial (Flynn, 2011, h. 67).

Beberapa kendala yang muncul dalam menjalankan peran dalam rumah tangga antara lain :

1. Gengsi dari pihak laki-laki. Permasalahan terkait tanggung jawab domestik dapat menjadi proses yang sulit. Pertama pembagian kerja tradisional antar jenis kelamin telah menyatakan bahwa laki-laki yang seharusnya bekerja dan perempuan mengurus rumah. Karena pekerjaan rumah yang identik dengan kaum perempuan seringkali disepelekan, maka ketika terjadi pertukaran peran terkait tanggung jawab domestik, pihak lakilaki akan sulit untuk menerima dan menyesuaikan diri.

2. Gengsi dari pihak perempuan. Kaum perempuan juga sebenarnya sulit untuk menyerahkan tanggung jawab atas pekerjaan domestik pada kaum laki-laki. Perempuan kadang merasa lebih cakap melakukan perkerjaan tersebut, sehingga peralihan tanggung jawab ini dapat berpengaruh negatif pada rasa percaya diri perempuan.

3. Standar tanggung jawab domestik. Perempuan dan laki-laki memiliki standar yang berbeda dalam melakukan berbagai pekerjaan domestik. Laki-laki cenderung lebih toleran sementara perempuan cenderung lebih resik dan teliti. Perbedaan standar ini dapat menyebabkan konflik di dalam rumah tangga 
4. Rasa bersalah. Rasa bersalah kerap kali dirasakan oleh perempuan saat mereka harus meninggalkan keluarga untuk mencari nafkah. Rasa bersalah ini dapat muncul karena adanya norma atau kepercayaan dalam masyarakat bahwa perempuan seharusnya mengurus rumah tangga sehingga ketika mereka harus bekerja, mereka merasa menelantarkan keluarga. (Wienclaw, 2011, h. 79 -83)

\section{Sosok Suami para Tenaga Kerja Wanita di Indonesia}

Ketika tuntutan ekonomi dan berbagai keadaan lain mengharuskan kaum perempuan untuk menjadi tulang punggung dan mencari nafkah bagi keluarga mereka, maka idealnya para suami mendukung, memahami dan dengan sukarela mengambil alih tanggung jawab untuk mengurus rumah tangga dan anak-anak. Namun pada kenyataannya hal ini masih jarang sekali ditemukan. Muzakki (2017, h. 1) memaparkan dalam keluarga $\mathrm{TKW}$, banyak suami yang tidak mendukung perjuangan istri mereka. Namun mereka merasa berhak menikmati hasil jerih payah istri-istri mereka. Uang yang seharusnya digunakan untuk keluarga malah disalahgunakan dan digunakan untuk membiayai berbagai perilaku menyimpang, seperti mabuk, menjalin hubungan dengan wanita lain atau berjudi.

Beberapa studi terdahulu memperlihatkan bahwa terdapat berbagai fenomena terkait dengan kehidupan rumah tangga yang dijalani oleh para TKW dan pasangan mereka, antara lain perselingkuhan, kiriman uang yang tidak digunakan dengan semestinya, suami malas bekerja, hingga perceraian. Serikat Buruh Migran Indonesia (SBMI) menjelaskan bahwa seringkali terdapat masalah komunikasi yang tidak lancar antara para TKW dengan suami mereka, dan hal inilah yang menyebabkan munculnya persoalan dalam pernikahan. Perceraian juga tidak terhindarkan karena masih banyak TKW yang menginginkan suami mereka juga bekerja dan mencari nafkah untuk keluarga, tidak hanya mengandalkan uang kiriman dari istri mereka. Namun sayangnya banyak suami yang tidak mau bekerja dan bergantung sepenuhnya pada istri mereka (Lestari, 2016, h. 1).

Penelitian yang dilakukan oleh Hendri Restuadhi terkait dengan hubungan suami-istri pada keluarga buruh migran perempuan di kabupaten Banyumas juga memperlihatkan bahwa sebagian besar suami enggan menjalankan peran untuk mengurus rumah tangga. Para suami ini merasa bahwa selama istri mereka bekerja di luar negeri, mereka dapat memenuhi naluri dan kebutuhan mereka dengan mencari pasangan lain, sehingga banyak ditemukan diantara mereka yang menjadi langganan di tempat prostitusi atau menjalin hubungan dengan perempuan lain (buruhmigran.or.id)

\section{METODE PENELITIAN}

Kajian ini menggunakan pendekatan kualitatif dengan metode semiotika Roland Barthes. Sobur (2003, h. 63) dalam Vera (2014, h. 27) mengatakan bahwa teori semiotik Barthes hampir secara harfiah diturunkan dari teori bahasa menurut de Saussure. Roland Barthes mengungkapkan bahwa bahasa merupakan sebuah sistem tanda yang mencerminkan asumsi-asumsi dari masyarakat dari masyarakat tertentu dalam waktu tertentu. Barthes juga meyakini bahwa hubungan antara penanda dan petanda tidak terbentuk secara alamiah, melainkan bersifat arbiter. Barthes juga melihat aspek lain dari penandaan, yaitu "mitos" yang menandai suatu masyarakat (Vera, 2014, h. 27). Tanda dibagi Barthes menjadi denotatif yang merupakan tataran pertama dengan makna eksplisit,langsung, pasti dan merujuk pada realitas. Sementara tanda konotatif merupakan tandayang memiliki keterbukaan makna yang implisit, tidak langsung, dan tidak pasti. Artinya terbuka kemungkinan terhadap penafsiranpenafsiran baru (Vera, 2014, h. 28).

\section{PEMBAHASAN}




\section{Sinetron Dunia Terbalik}

Sinetron Dunia Terbalik mengisahkan mengenai empat orang lakilaki yang bertempat tinggal di Desa Cikadu, yaitu Akum, Aceng, Dadang, dan Idoy yang ditinggal istri mereka untuk mencari nafkah sebagai TKW ke luar negeri. Ke empat laki-laki digambarkan sebagai sosok suami yang ideal, berperan sebagai bapak rumah tangga yang mengerjakan berbagai pekerjaan domestik seperti mengurus urusan rumah, mendidik anak, memasak, dan berbelanja berbagai kebutuhan seharihari ("EKSKLUSIF: Sinetron "Dunia Terbalik" Puncaki Rating, Ini Komentar Sutradara", 2017).

Dalam kehidupan sehari-hari para suami ini juga digambarkan memiliki sifat dan melakukan berbagai aktivitas yang biasanya dilakukan oleh para Ibu Rumah Tangga, mulai dari arisan, bergunjing dengan teman dan tetangga, bahkan saling menyombongkan kekayaan dan gaji istri mereka masing-masing. Di waktu senggang, mereka kadang melakukan berbagai pekerjaan untuk membantu perekonomian keluarga, seperti menjadi tukang ojek atau makelar jual beli tanah, bangunan, dan berbagai hal lainnya.

\section{Hiperrealitas Sosok Suami Ideal dalam Sinetron Dunia Terbalik}

Sosok suami yang ditampilkan dalam sinetron ini merupakan sosok suami ideal yang merupakan simulasi dan hiperrealitas yang menutupi fakta; sehingga sosok suami yang ditampilkan dalam sinetron ini bukanlah realitas yang nyata, namun realitas palsu yang tidak mengacu pada kondisi yang sebenarnya.

\section{Adegan 1}

Penanda

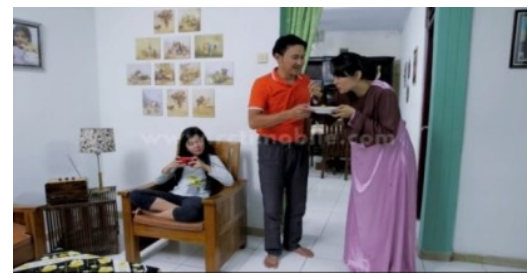

Gambar 1. Tokoh Akum memasak bagi keluarganya.

\section{Petanda}

Adegan 1 merupakan potongan dari salah satu episode dari sinetron Dunia Terbalik, dimana salah seorang suami (Akum) mempersiapkan masakan istimewa bagi istri dan anak-anaknya. Selain memasak, Akum juga sudah membersihkan dan menata rumah agar istrinya merasa nyaman dan dapat beristirahat dengan tenang. Hal ini dilakukan Akum karena ia merasa bahwa mengurus rumah termasuk memasak adalah tanggung jawabnya.

\section{Analisis}

Adegan ini menggambarkan sebuah hiperrealitas mengenai suami TKW yang sukarela mengambil alih pekerjaan rumah tangga, dan tetap melakukan peran mereka saat sang istri berada di rumah.

Pada kenyataannya Wienclaw (2011, h. 7983) menjelaskan bahwa permasalahan terkait tanggung jawab domestik merupakan hal yang kompleks, karena adanya pandangan yang menyepelekan pekerjaan rumah tangga yang identik dengan kaum perempuan; sehingga saat terjadi pertukaran peran terkait tanggung jawab domestik, pihak laki-laki akan sulit untuk menerima hal ini. Saat seorang lakilaki melakukan pekerjaan domestik, ia akan merasa disepelekan, terlebih lagi apabila ia melakukan pekerjaan itu di depan istri mereka atau orang lain.

Sinetron ini mengambil latar belakang di sebuah pedesaan kawasan Jawa Barat yang sejatinya masih menganut budaya patriarki, dimana laki-laki selalu identik sebagai kepala rumah tangga dan pencari nafkah utama. Dalam budaya ini seorang laki-laki akan mengalami berbagai pertentangan batin terkait dengan pertukaran peran yang dijalaninya. Pandangan masyarakat terhadap peran "bapak rumah tangga" dapat menimbulkan konflik di dalam rumah tangga.

Selain itu Sajogyo dalam Yuniastuti (2014, h. 66) menjelaskan bahwa jika seorang perempuan turut memainkan peran secara ekonomi, bukan berarti peran domestik atau kodratnya sebagai ibu rumah tangga akan menjadi gugur. Sebaliknya ia memainkan 
peran ganda. Peran ganda yang dimiliki perempuan terdiri atas: (1) peran dalam hubungan dengan pekerjaan rumah tangga atau pemeliharaan kebutuhan hidup semua anggota keluarga dalam rumah tangga, dan (2) peran dalam hubungan dengan kegiatan usaha untuk mencari nafkah. Oleh karena itu meski istri menjadi tulang punggung keluarga,biasanya ia tidak serta merta bertindak sebagai seorang pemimpin dan memerintah suaminya di depan orang lain. Suami tetap akan dihormati sebagai kepala rumah tangga oleh sang istri.

\section{Adegan 2}

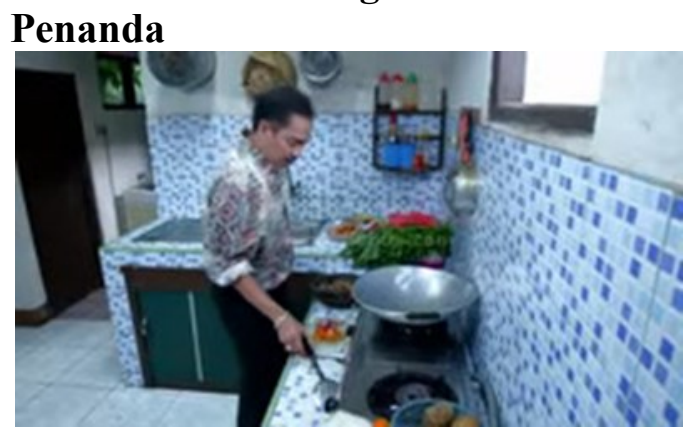

Gambar 2. Tokoh Dadang dengan terampil menyiapkan makanan.

\section{Petanda}

Adegan ini memperlihatkan salah satu tokoh suami (Dadang) yang sedang memasak Dadang selalu memasak untuk keluarganya setiap hari, mulai dari menyiapkan sarapan hingga memasak makan malam. Penggambaran adegan ini ditampilkan secara kronologis, mulai dari mulai dari mencuci sayuran, mengiris bumbu, hingga menumis masakan.

\section{Analisis}

Adegan ini merupakan simulasi yang menampilkan hiperrealitas suami rajin dan terampil memasak. Pada kenyataannya hal ini jarang dapat ditemui di dalam kehidupan keluarga TKW. Biasanya suami dari para TKW tersebut tidak mau mengurus rumah tangga, dan memilih untuk menjalin hubungan dengan wanita lain yang dapat mengurus dan melayani kebutuhan mereka (Muzakki, 2017, hal. 1). Para suami TKW seringkali mengandalkan pihak lain untuk berbagai pekerjaan rumah tangga, baik dari keluarga (anak perempuan, orang tua), maupun wanita lain.

Wienclaw (2011, h.79-83) menyatakan bahwa standar pekerjaan domestik antara laki-laki dan perempuan berbeda, dimana laki-laki cenderung lebih santai sementara perempuan lebih resik dan tertata. Hal ini mengimplikasikan bahwa dalam melakukan kegiatan domestik seperti memasak, laki-laki tidak serajin perempuan. Sehingga penggambaran sosok suami yang rajin memasak tiga kali sehari dapat dikatakan sebagai sebuah hiperrealitas.

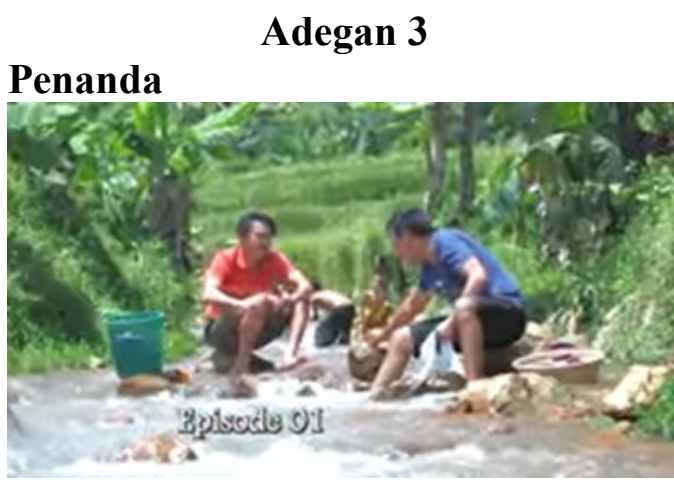

Gambar 3. Tokoh Akum dan Aceng mencuci pakaian di sungai

\section{Petanda}

Adegan ini memperlihatkan dua orang lakilaki, yaitu Akum dan Aceng yang sedang mencuci pakaian di sungai sambil membicarakan salah seorang kawan mereka yang mendapatkan kiriman handphone seri terbaru dari istrinya yang bekerja diluar negeri. Padahal kegiatan lazimnya dikerjakan oleh para istri atau ibu rumah tangga. Akum dan Aceng diperlihatkan sangat menantikan aktivitas mencuci bersama karena mereka dapat berkumpul dan saling memberikan informasi mengenai teman mereka.

\section{Analisis}

Sosok suami dalam adegan ini ditampilkan sebagai sosok yang sangat rajin, tidak malu mengerjakan pekerjaan rumah tangga, dan menikmati pekerjaan domestik yang mereka lakukan. Hal ini merupakan sebuah hiperrealitas, karena bertolak belakang dengan dengan stereotype yang melekat 
pada kaum laki-laki. Laki-laki selalu diasosiasikan dengan maskulinitas, kesuksesan, dan kekuatan. Apabila suami dengan rela mengambil alih peran untuk melakukan berbagai pekerjaan domestik, hal ini akan dilakukan secara tertutup. Selain itu kegemaran bergunjing yang ditampilkan juga merupakan sesuatu yang "khas" perempuan, dan jarang ditemukan sosok suami yang senang membicarakan orang lain secara terbuka seperti yang ditampilkan pada adegan ini.

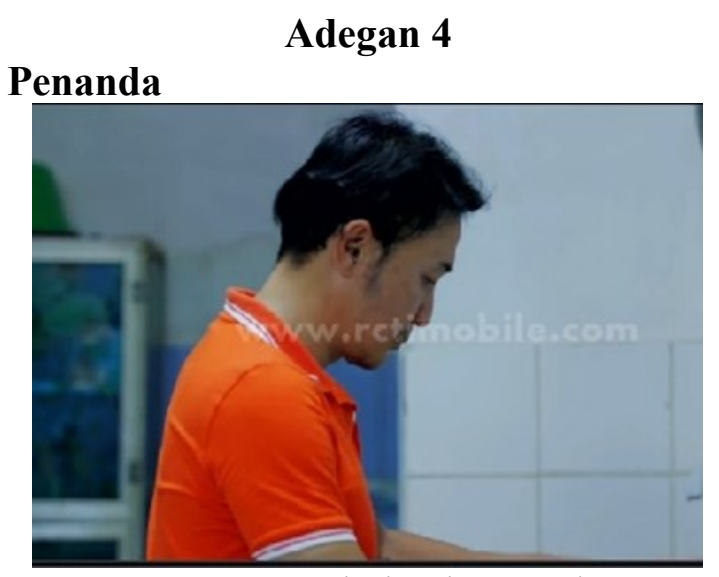

Gambar 4. Tokoh Akum sedang mengingat istrinya yang bekerja di luar negeri.

\section{Petanda}

Dalam adegan ini Akum menceritakan kerinduan dan kasih sayangnya kepada sang istri kepada anak perempuannya serta berjanji pada sang anak bahwa ia tidak akan menjalin hubungan dengan wanita lain. Hal ini diutarakan Akum ketika sang anak melihat ada beberapa perempuan yang jelas-jelas menyatakan ketertarikan mereka pada ayahnya; namun Akum menepis dan tidak memperdulikannya.

\section{Analisis}

Penggambaran ini menjadi sebuah hiperrealitas yang menutupi fakta bahwa sebenarnya kehidupan TKW biasanya selalu diwarnai dengan perselingkuhan dan perceraian. Penelitian terdahulu yang dilakukan oleh Hendri Restuadhi terkait dengan hubungan suami-istri pada keluarga buruh migran perempuan di kabupaten Banyumas memperlihatkan bahwa para suami ini merasa mereka dapat memenuhi naluri dan kebutuhan mereka dengan mencari pasangan lain, sehingga banyak ditemukan diantara mereka yang menjadi langganan di tempat prostitusi atau menjalin hubungan dengan perempuan lain (buruhmigran.or.id)

\section{SIMPULAN}

Dari kajian ini terlihat bahwa bahwa hiperrealitas dalam sinetron "Dunia Terbalik" ditampilkan melalui sosok suami yang bertindak sebagai bapak rumah tangga yang ikhlas, rajin dan terampil melakukan berbagai pekerjaan domestik serta setia terhadap istri mereka yang bekerja di luar negeri. Hiperrealitas yang ditampilkan memperlihatkan adanya peranan baru bagi suami dan peletakan kekuasaan di tangan istri. Hal ini dapat dilihat sebagai sebuah pergeseran pemikiran dari kalangan industri hiburan dan pemilik media massa terkait dengan peran dan tanggung jawab laki-laki dan perempuan di dalam masyarakat Indonesia yang memiliki budaya patriarki.

Namun tidak dapat dikesampingkan bahwa masih terdapat motif ekonomi yang melatarbelakangi sinetron ini. Unsur komedi yang kental terlihat melalui adeganadegan dimana para tokoh laki-laki melakukan berbagai hal yang biasanya dilakukan oleh perempuan, seperti bergosip, iri dengan tetangga, atau bertengkar dengan laki-laki lainnya. Adegan-adegan inilah yang banyak ditonjolkan dalam sinteron Dunia Terbalik, sehingga peralihan peran suami dan istri hanya terlihat sebagai pemanis saja. Meski begitu, hiperrealitas yang diperlihatkan pada sinetron ini dapat memunculkan kesadaran akan kesetaraan gender, serta dapat berkontribusi dalam menghapuskan stigma negatif yang melekat pada kalangan TKW serta keluarga mereka.

\section{DAFTAR PUSTAKA}

1. Chardon, L., Comm-entary (1st ed., pp. 126-136). New Hampsire: University of New Hampsire. Retrieved from 
http://cola.unh.edu/communication/co mm-entary, 2014.

2. Flynn, S., Family Gender Roles in Sociology Reference Guide : Gender Roles \& Equality $1^{\text {st }}$ ed., Pasadena, Salem Press, 2011.

3. Gauntlett, D.,Media, Gender and Identity (1st ed.), Johanneshov: TPB, 2011.

4. Haryatmoko, Membongkar Rezim Kepastian: Pemikiran Kritis PostStrukturalis, Yogyakarta, PT Kanisius, 2016.

5. Lestari, S., Keluarga TKI di Indramayu Rentan Terkena Dampak Psikologi \& Sosial, Retrieved 16 May 2017, from http://www.bbc.com/indonesia/majala h/2016/01/160124-majalahburuhmigran-indramayu, 2016.

6. Lubis, A., Pemikiran Kritis Kontemporer: Dari Teori Kritis, Culture Studies, Feminisme, Postkolonial hingga Multikulturalisme. Jakarta, PT Raja Grafindo Persada, 2015.

7. Mann, D. (n.d). Baudrillard Short Introduction. Publish.uwo.ca. Retrieved 29 March 2017, from http://publish.uwo.ca/ dmann/baudrill ard1.htm

8. Muzakki, K., retrieved 25 March 2017, from

http://www.tribunnews.com/regional/2 016/11/23/memprihatinkan-kelakuansuami-tkw-saat-ditinggal-istri-bekerjadi-luar-negeri, 2017.

9. O'Donnel, K.,Postmodernisme, Yogyakarta, PT Kanisius, 2009.

10. Saputra, E.E., Hiperrealitas Relasi dalam Sinetron Komedi "Tetangga Masa Gitu?”, Departemen Sosiologi, Fakultas Ilmu Sosial dan Ilmu Politik, Universitas Indonesia, 2016

11. Syafitri, W., Determinants of Labor Migrations Decisions : The Case of East Java, Retrieved March 3, 2016, from http://www.unikassel.de/upress/online/frei/978-386219-314-1.volltext.frei.pdf, 2012.
12. Serikat Buruh Migran Indonesia. Rerieved 16 May 2017 from https://buruhmigran.or.id/suami-tki, 2016.

13. Vera, Nawiroh., Semiotika dalam Riset Komunikasi, Bogor, Penerbit Ghalia Indonesia, 2014.

14. Wienclaw, R.A., Gender and Domestic Responsibility" in Sociology Reference Guide: Gender Roles \& Equality $1^{\text {st }}$ ed., Pasadena, Salem Press, 2011.

15. Yuniastuti, Kehidupan Sosial Ekonomi TKI dan TKW Serta Dampak Sosial Psikologis Pendidikan Anak, Jurusan Hukum dan Kewarganegaraan Universitas Negeri Malang, 2014.

16. "EKSKLUSIF: Sinetron "Dunia Terbalik" Puncaki Rating, Ini Komentar Sutradara. (2017). Tabloidbintang.com. Retrieved 25 March 2017, from http://www.tabloidbintang.com/article s/film-tv-musik, 2017. 